Чукурна О.П.

канд. економ. наук, доцент

Одеській національний політехнічний університет

\title{
ВДОСКОНАЛЕННЯ МЕТОДІВ МАРКЕТИНГОВОГО ЦІНОУТВОРЕННЯ МАШИНОБУДІВНИХ ПІДПРИЕМСТВ
}

\section{СОВЕРШЕНСТВОВАНИЕ МЕТОДОВ МАРКЕТИНГОВОГО ЦЕНООБРАЗОВАНИЯ МАШИНОСТРОИТЕЛЬНЫХ ПРЕДПРИЯТИЙ}

\section{IMPROVING MARKET PRICING METHODS OF MACHINE-BUILDING ENTERPRISES}

В статті розглянуто витратні методи встановлення ціни на підприємствах машинобудування. Проаналізовані традииійні підходи до маркетингового ичіноутворення та запропоновано вдосконалити витратні методи маркетингового иіноутворення за рахунок використання корелячійно-регресійного аналізу. В прочесі проведення кореляиійнорегресійного аналізу були виявлені 3 основних витратних фактора, які мають найбільший вплив в структурі ціни на продукцію українських підприємств машинобудування. Визначено вплив найбільш вагомих витратних факторів в структурі ціни. Запропоновано метод питомої иіни, який повинен базуватися на питомій вазі кожного фактору в структурі иіни. Цей підхід дозволить враховувати низьку факторів ціноутворення, які притаманні галузі машинобудування. Цей підхід до ціноутворення дозволяє об'єктивно відокремлювати специфічні фактори, які мають місие в різних підгалузях машинобудування та враховувати їх при формуванні ціни на свою продукцію. Запропоновано алгоритм встановлення кінщевої ціни.

Ключові слова: методи ціноутворення, регресія, кореляція, машинобудування, фактори ціноутворення, питома ціна.

В статье рассмотрены затратные методы установления ценны на предприятиях машиностроения. Проанализированы традиционые подходы $\kappa$ маркетинговому ценообразованию и предложено усовершенствовать затратные методы маркетингового ценообразования за счет использования коррелячиионно-регрессионного анализа. В прочессе проведения коррелячионно-регрессионного анализа были выявлены 3 основных затратных фактора, которые оказывают наибольшее влияние в структуре иены на продукцию украинских предприятий машиностроения. Определено влияние наиболее значимых затратных факторов в структуре иены. Предложен метод удельной цены, который базируется на удельном весе каждого фактора в структуре иены. Этот подход позволяет учитывать те факторы иенообразования, которые имеют место в сфере машиностроения. Этот подход к иенообразованию позволяет объективно выделять спечифические факторы, которые проявляются в различных подотраслях машиностроения и учитывать их при формировании цены на свою продукцию. Предложен алгоритм установления конечной цены.

Ключевые слова: методы ценообразования, регрессия, корреляция, машиностроение, факторы ценообразования, удельная цена. 
The article describes the expensive methods of establishing the price of machine-building enterprises. Analysed the traditional approaches to marketing and pricing made for better cost methods of marketing pricing through the use of regression analysis. In the process of correlation and regression results we identified three main cost factors that have the greatest impact in the structure of prices for the products of the Ukrainian enterprises of mechanical engineering. The influence of the most significant cost factor in the price structure. The method of the unit price, which was based on the specific weight of each factor in the structure of prices. This approach takes into account the factors of pricing that take place in the field of mechanical engineering. This approach to pricing allows you to objectively separate the specific factors that manifest themselves in different sub-sectors of mechanical engineering and take them into account in the formation of prices for their products. Suggested algorithm for setting the final price.

Keywords: pricing methods, regression, correlation, engineering, pricing factors, the specific price

Вступ. В сьогоденні в концепції маркетингового ціноутворення застосовуються два окремих метода: метод регресійного аналізу та метод питомої ціни. Але, застосування методів регресійного аналізу та методу питомої ціни в маркетинговому ціноутворенні має дуже обмежений характер. Вони використовуються виключно при ціноутворенні на новий або модифікований товар в контексті групи нормативно-параметричних методів.

В умовах розвитку глобальної економіки та формування впливу нових факторів глобального порядку на методологію ціноутворення, постає питання визначення факторів найбільшого впливу на процес встановлення ціни. В цьому механізмі, найбільш надійну інформацію можна отримати при використанні методів регресійного аналізу, який надає можливість отримати інформацію щодо факторів, які мають найбільший вплив та питому вагу в структурі ціни. Таким чином, методологія маркетингового ціноутворення змінюється шляхом формування нових методів та методик формування ціни.

Дослідження різних аспектів маркетингового ціноутворення знайшло відображення у наукових працях провідних зарубіжних та вітчизняних вчених, до яких можна віднести: Ф. Котлера [3,4], М. Портера [6], П. Друкера [2], Л. Балабанову[1], Н. Ревуцьку[7], Л. Шульгіну[8], Н. Чухрай та інших. Незважаючи на вагомий внесок цих вчених в розвиток концепції маркетингового ціноутворення, на сьогодні немає цілісної системи знань, яка має охоплювати низьку факторів, що впливають на встановлення ціни в різних галузях промисловості, в тому числі й машинобудуванні.

Постановка завдання. 3 метою вдосконалення методів ціноутворення машинобудівних підприємств в даному досліджені було проведено аналіз впливу на кінцеву ціну структури витрат на виробництво та збут машинобудівної продукції за допомогою кореляційно - регресійного аналізу. Передбачається вдосконалення методів маркетингового ціноутворення, що базується на визначенні питомої ваги кожного фактору ціноутворення в структурі кінцевої ціни за допомогою кореляційно-регресійного аналізу. 
Методологія. В процесі написання статті використані наступні економіко-статистичні методи: кореляційний аналіз 3 метою виявлення найбільших кореляційних зв`язків між факторами, що впливають на ціноутворення; регресія, з метою побудови рівняння, за допомогою якого отримані прогнозі значення цін на продукцію машинобудування; методів систематизації 3 метою формування висновків та рекомендацій щодо вдосконалення методів маркетингового ціноутворення.

Результати дослідження. Згідно існуючої системи методів щодо маркетингового ціноутворення, метод регресійного аналізу передбачає, що продавець встановлює ціни за формулою регресійної залежності рівня ціни від значень техніко-економічних параметрів виробів того параметричного ряду, до якого належить новий товар. Ціна виступає як функція зростаючих техніко-економічних параметрів нового товару. В загальному вигляді регресійна залежність між змінами факторних $\left(x_{n}\right)$ і результативної $(P)$ ознак визначається за наступною формулою (1):

$$
\begin{aligned}
& P=\int\left(x_{1}, x_{2}, x_{3}, \ldots x_{n}\right), \\
& \text { де } P \text { - ціна товару; } \\
& x_{1}, x_{2}, x_{3}, \ldots x_{n}-\text { техніко-економічні параметри. }
\end{aligned}
$$

По рівнянню регресії продавець отримує розрахункові значення цін всіх товарів певного параметричного ряду. При розрахунках найчастіше використовують такі функції: лінійну, лінійно-степеневу, логарифмічну, степеневу, показову, гіперболічну. Тіснота кореляційного зв'язку між ціною та сукупністю параметрів оцінюється за допомогою коефіцієнту множинної кореляції. Чим ближче значення коефіцієнту до одиниці, тим тісніший зв'язок параметру і ціни [5, с.58].

Застосування цього підходу до маркетингового ціноутворення обмежується розрахунком ціни товарів певного параметричного ряду. В свою чергу, метод питомої ціни використовується для визначення ціни товару якість якого характеризується одним домінуючим технікоекономічним параметром.

Ціна розраховується за наступним алгоритмом [5, с.58].

1. Розраховується питома ціна основного техніко-економічного параметру еталонного товару за наступною формулою:

$$
P_{n u m}=\frac{P_{E}}{\Pi_{E_{j}}},
$$

де $P_{n u m}$ - питома ціна основного техніко-економічного параметру еталонного товару;

$P_{E}$ — ціна еталонного товару;

$\Pi_{E j}$ - значення $j$ техніко-економічного параметру еталонного товару;

2. Розраховується ціна нового товару за наступною формулою: 
$P_{H}=P_{\text {num }} \times \Pi_{H_{j}}$,

де $P_{H}$ - ціна нового товару;

$\Pi_{H_{j}}$ - значення $j$ техніко-економічного параметру нового товару;

Класичний підхід щодо використання цих методів при ціноутворенні на продукцію машинобудівних підприємств можливо використовувати тільки на новий товар. В рамках даного дослідження пропонується використовувати метод регресійного аналізу при встановленні ціни на будь-які види продукції машинобудування. Основна ідея використання цього підходу полягає в тому, що кореляційно-регресійний аналіз дозволяє визначити вплив різних факторів в составі й структурі ціни та передбачає інструменти розрахунки питомої ціни. Таким чином, методологія кореляційно-регресійного аналізу дозволяє гнучко виявляти питому вагу та значущість різних факторів, які впливають на кінцеву ціну та швидко пристосовуватися до них в умовах зміни факторів маркетингової середи. Цей підхід набуває особливої актуальності в умовах глобалізації, оскільки на глобальних ринках діють нові фактори, які впливають на ціноутворення.

Проведений кореляційний аналіз факторів впливу на собівартість при використанні витратних методів ціноутворення дозволив виявити об'єктивні чинники впливу на формування собівартості та ступінь цього впливу. Внаслідок цього, при формуванні методології ціноутворення на продукцію машинобудівних підприємств пропонується використовувати наступний алгоритм процесу встановлення ціни, який буде виглядати як представлено на рис. 1.

Адаптована методологія ціноутворення на основі використання кореляційно-регресійного аналізу була апробована в розрахунках ціни машинобудівних підприємств. Фактором, який є найбільш підконтрольним при ціноутворенні, є витрати, тому при проведенні розрахунків були використані дані про склад та структуру витрат на підприємствах, які аналізувалися.

Об`єктом аналізу була середньозважена ціна на машинобудівну продукцію 4 великих українських вагонобудівельних підприємств та підприємств, які виробляють сільськогосподарську техніку та енергетичне обладнання й прибори. Аналіз проводився за період з 2008 по 2014pp.

Ці галузі машинобудування були обрані в якості об'єктів дослідження на основі попередніх розрахунків, результати яких дозволили дійти висновку щодо наявності перспектив їх подальшого розвитку. Вони характеризуються інноваційною активністю та високим ступенем орієнтації на експорт та виробництво електричних машин та обладнання, розвиток якого впливає на багато економічних показників країни. 


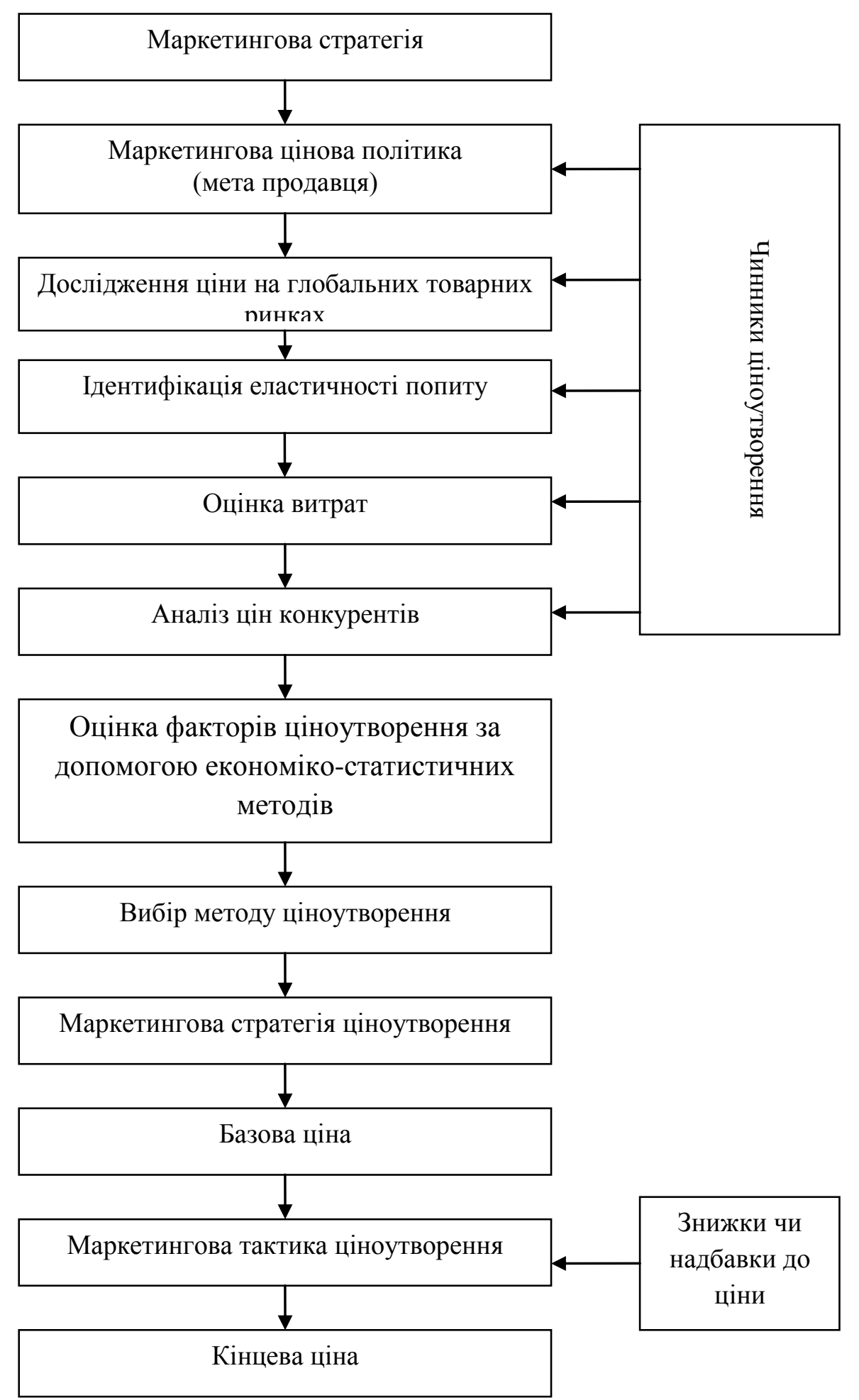

Рис.1. Алгоритм встановлення кінцевої ціни підприємства [розроблено автором]

Економічний аналіз ціноутворення в галузі машинобудування дозволив виявити, що ціна на продукцію підгалузей машинобудування, які 
досліджувалися, встановлюється витратним методом, на основі врахування повної собівартості. Виходячи 3 результатів попередніх розрахунків та виявлення кореляційних зв`язків між факторами впливу на процес ціноутворення, для проведення регресійного аналізу були обрані наступні фактори: собівартість реалізованої продукції, витрати на збут та адміністративні витрати. Ціна на підприємствах машинобудівної галузі встановлюється виключно на основі витрат, тому для виявлення зміни середньозваженої ціни за допомогою рівняння регресії, були взяті саме ці три фактори. Кореляційний аналіз впливу на середньозважену ціну таких факторів, як собівартість реалізованої продукції, витрати на збут та адміністративні витрати на українських машинобудівельних підприємствах представлено в таблиці 1.

Таблиця 1

Кореляційний зв язок та вплив витрат на середньозважену ціну продукції підприємств українського машинобудування [розроблено

\begin{tabular}{|c|c|c|c|c|}
\hline \multicolumn{5}{|c|}{ автором ] } \\
\hline & & \multicolumn{3}{|c|}{ коефіцієнт кореляції } \\
\hline & галузь & $\begin{array}{c}\text { Собівартість } \\
\text { реалізованої } \\
\text { продукції } \\
\text { (X1) }\end{array}$ & $\begin{array}{c}\text { Витрати на } \\
\text { збут (X2) }\end{array}$ & $\begin{array}{l}\text { Адміністр } \\
\text { ативні } \\
\text { витрати } \\
\text { (Х3) }\end{array}$ \\
\hline ПАТ "Азовмаш" & вагонобудування & $-0,16$ & $-0,016$ & $-0,25$ \\
\hline ПАТ "Дніпровагонмаш" & вагонобудування & 0,89 & 0,89 & 0,89 \\
\hline $\begin{array}{c}\text { ПАТ "Крюковській } \\
\text { вагонобудівельний завод" }\end{array}$ & вагонобудування & 0,97 & 0,58 & 0,66 \\
\hline $\begin{array}{c}\text { ПАТ "Стахановській } \\
\text { вагонобудівельний завод" }\end{array}$ & вагонобудування & 0,53 & 0,41 & 0,51 \\
\hline ПАТ "Уманьфермаш" & $\begin{array}{c}\text { сільсько } \\
\text { господарське } \\
\text { машинобудування }\end{array}$ & 0,80 & 0,93 & 0,92 \\
\hline ПАТ "Спецавтоматика" & $\begin{array}{c}\text { виробництво } \\
\text { протипожежних } \\
\text { приладів }\end{array}$ & $-0,85$ & $-0,66$ & $-0,88$ \\
\hline Телекартприбор & $\begin{array}{c}\text { виробництво } \\
\text { приладів } \\
\text { контролю } \\
\end{array}$ & 0,74 & 0,79 & 0,77 \\
\hline
\end{tabular}

Проведені розрахунки підтверджують, що підприємства машинобудування орієнтуються на витратний підхід, оскільки для всіх характерним $\epsilon$ високий вплив собівартості на середню ціну. Виключенням $\epsilon$ тільки ПАТ «Азовмаш», де спостерігається зворотній вплив, тобто ціна впливає на собівартість, причому на незначному рівні. Витрати на збут мають високий вплив на ціну тільки на ПАТ «Уманьферммаш» $(\mathrm{R}=0,81)$. Середній 
вплив на ціну показника збутових витрат мають на ПАТ «Дніпровагонмаш» та ПАТ «Крюковський вагонобудівельний завод» $(\mathrm{R}=0,60$ та $\mathrm{R}=0,58)$. Найбільший вплив адміністративних витрат на середньозважену ціну спостерігається в ПАТ «Уманьферммаш» $(\mathrm{R}=0,93)$ та середній вплив вони мають також на ПАТ «Дніпровагонмаш» та ПАТ «Крюковський вагонобудівельний завод» $(\mathrm{R}=0,54$ та $\mathrm{R}=0,66)$. На рис. 2 представлена тіснота кореляційних зв`язків між собівартістю, витратами на збут та адміністративними витратами машинобудівельних підприємств.

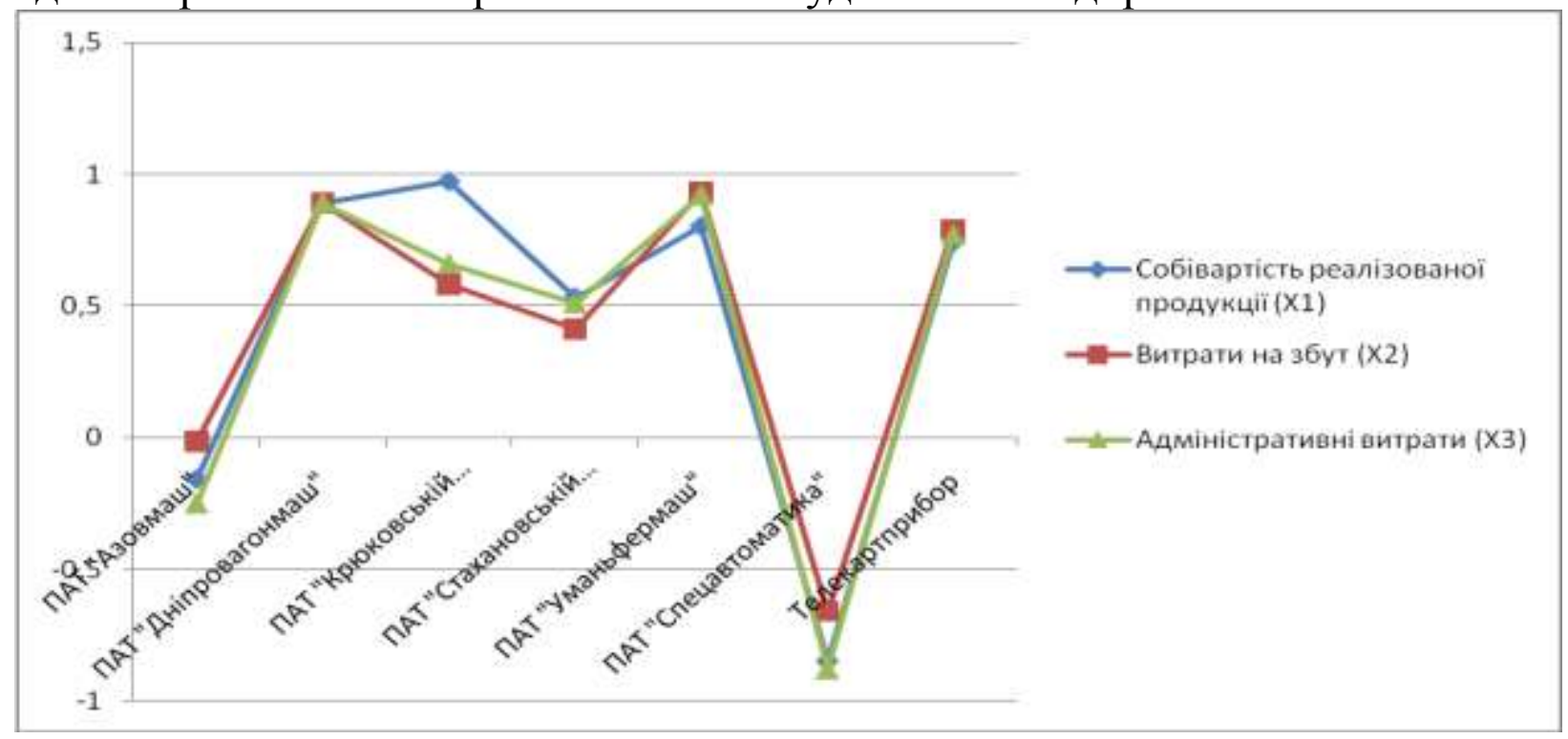

Рис. 2. Тіснота кореляційних зв’язків між собівартістю, витратами на збут та адміністративними витратами машинобудівельних підприємств

Для порівняння показників рентабельності в структурі ціни на продукцію машинобудування була складена таблиця 2.

Таблиця 2

Рівень рентабельності в структурі середньозваженої ціни на продукцію підприємств машинобудування (\%)[розроблено автором]

\begin{tabular}{|c|c|c|c|c|c|c|c|}
\hline Рік & $\begin{array}{l}\text { ПАТ } \\
\text { "Азов } \\
\text { маш" }\end{array}$ & $\begin{array}{c}\text { ПАТ } \\
\text { "Дніпро } \\
\text { вагон } \\
\text { маш" }\end{array}$ & $\begin{array}{c}\text { ПАТ } \\
\text { "Крюковсь } \\
\text { кий } \\
\text { вагонобуді } \\
\text { вельний } \\
\text { завод" }\end{array}$ & $\begin{array}{c}\text { ПАТ } \\
\text { "Стахановс } \\
\text { ький } \\
\text { вагонобуді } \\
\text { вельний } \\
\text { завод" }\end{array}$ & $\begin{array}{c}\text { ПАТ } \\
\text { "Умань } \\
\text { ферм } \\
\text { маш" }\end{array}$ & $\begin{array}{c}\text { ПАТ } \\
\text { "Спец } \\
\text { автома } \\
\text { тика" }\end{array}$ & $\begin{array}{c}\text { Телекарт } \\
\text { прибор }\end{array}$ \\
\hline 2008 & 98,6 & 24,9 & 27,5 & 12,07 & 19,3 & 4,29 & 99,93 \\
\hline 2009 & 97,7 & 12,1 & 8 & $-1,59$ & 15,5 & $-8,04$ & 99,90 \\
\hline 2010 & 94,9 & - & 18,9 & 7,83 & 17,3 & 2,01 & 99,78 \\
\hline 2011 & 99,5 & 26,9 & 21 & 3,00 & 19,8 & $-19,35$ & 99,67 \\
\hline
\end{tabular}




\begin{tabular}{|c|c|c|c|c|c|c|c|}
2012 & 99,5 & 34,7 & 14,2 & $-7,17$ & 19,3 & $-18,18$ & 94,27 \\
\hline 2013 & 99,04 & 0,7 & 10,5 & $-504,79$ & 38,9 & 219,69 & 95,74 \\
\hline 2014 & - & 40,8 & 0,94 & $-259,37$ & 49,7 & 232,93 & 96,53 \\
\hline
\end{tabular}

Згідно 3 розрахунками за даними фінансової звітності підприємств машинобудування, рівень рентабельності у підприємств однієї підгалузі машинобудування є різним. У ПАТ «Азовмаш» спостерігається найбільший рівень рентабельності не тільки серед підприємств вагонобудівельної галузі, але й серед підприємств інших підгалузей машинобудування. 3 таблиці 2 видно, що рівень рентабельності продукції ПАТ «Азовмаш» має показник від 94\% до 99\%. Це свідчить про те, що підприємство має значні переваги за витратами та володіє унікальними видами продукції, які не мають аналогів на товарних ринках. У ПАТ «Дніпровагонмаш» та ПАТ «Крюковській вагонобудівельний завод» рівень рентабельності знаходиться на одному рівні, але має значні коливання за період, який аналізується. Найнижчий рівень рентабельності серед підприємств машинобудування спостерігається у ПАТ «Стахановський вагонобудівельний завод».

Регресійний аналіз трьох основних показників витрат в структурі ціни підприємств машинобудування, які аналізувалися, дозволив сформувати рівняння для розрахунку прогнозних значень ціни (табл. 3).

Таблиця 3

Регресійні рівняння для розрахунків зміни ціни для підприсмств українського машинобудування [розроблено автором]

\begin{tabular}{|c|c|}
\hline & Регресійні рівняння для розрахунків ціни \\
\hline ПАТ "Азовмаш" & $\mathrm{Y}=846,5-17,95 * \mathrm{X} 1+84,71 * \mathrm{X} 2-46,002 * \mathrm{X} 3$ \\
\hline ПАТ "Дніпровагонмаш" & $\mathrm{Y}=620,14-1,35 * \mathrm{X} 1+59,62 * \mathrm{X} 2-18,46 * \mathrm{X} 3$ \\
\hline $\begin{array}{c}\text { ПАТ "Крюковській } \\
\text { вагонобудівельний завод" }\end{array}$ & $\mathrm{Y}=170,13+1,02 * \mathrm{X} 1+1,18 * \mathrm{X} 2-5,15 * \mathrm{X} 3$ \\
\hline $\begin{array}{c}\text { ПАТ "Стахановській } \\
\text { вагонобудівельний завод" }\end{array}$ & $\mathrm{Y}=817,98+8,87 * \mathrm{X} 1-0,0085 * \mathrm{X} 2-0,0019 * \mathrm{X} 3$ \\
\hline ПАТ "Уманьфермаш" & $\mathrm{Y}=396,6 * \mathrm{X} 1+11267,3 * \mathrm{x} 2+6828,36 * \mathrm{X} 3-7961,33$ \\
\hline $\begin{array}{c}\text { ПАТ "Спецавтоматика" } \\
\text { релекартприбор }\end{array}$ & $\mathrm{Y}=2955,63-6241,41 * \mathrm{X} 1-89589,42 * \mathrm{X} 2+71871,06 * \mathrm{X} 3$ \\
\hline \multicolumn{2}{|c|}{ розрахунку } \\
\hline Методика середньозваженої
\end{tabular}

машинобудування ціни за допомогою кореляційно-регресійного методу надає змогу виявити найбільш вагомі фактори, які впливають на ціну. Крім того, отримане рівняння регресії сприяє розрахункам прогнозних значень ціни, які 
можна покласти в плани маркетингу на підприємствах. За допомогою регресійних рівнянь, які були отримані розраховано зміну середньозваженої ціни на продукцію українських підприємств машинобудування (табл.4).

Таблиця 4

Зміна середньозваженої ціни на продукцію підприсмств машинобудування за допомогою формул, отриманих в результаті регресійного аналізу (тис. грн.) [розроблено автором на основі розрахунків з даних форм звітності підприємств]

\begin{tabular}{|c|c|c|c|c|c|c|c|}
\hline Рік & $\begin{array}{c}\text { ПАТ } \\
\text { "Азовма } \\
\text { ш" } \\
\end{array}$ & $\begin{array}{c}\text { ПАТ } \\
\text { "Дніпр } \\
\text { овагон } \\
\text { маш" }\end{array}$ & $\begin{array}{c}\text { ПАТ } \\
\text { "Крюков } \\
\text { ський } \\
\text { вагоноб } \\
\text { удівельн } \\
\text { ий } \\
\text { завод" } \\
\end{array}$ & $\begin{array}{c}\text { ПАТ } \\
\text { "Стахановс } \\
\text { ький } \\
\text { вагонобуді } \\
\text { вельний } \\
\text { завод" } \\
\end{array}$ & $\begin{array}{c}\text { ПАТ } \\
\text { "Умань } \\
\text { ферммаш" }\end{array}$ & $\begin{array}{c}\text { ПАТ } \\
\text { "Спецав } \\
\text { томатик } \\
\text { a" } \\
\end{array}$ & $\begin{array}{l}\text { Телекар } \\
\text { тприбор }\end{array}$ \\
\hline 2008 & 500 & 391,5 & 500 & 500 & 37452 & 387,5 & 1978,5 \\
\hline 2009 & 600 & 281,99 & 600 & 600 & 49043,93 & 465,09 & 2525,2 \\
\hline 2010 & 700 & 400,5 & 700 & 650 & 70657,18 & 517,6 & 2735,6 \\
\hline 2011 & 800 & 450,8 & 800 & 690 & 74352,57 & 573,04 & 2555,4 \\
\hline 2012 & 800 & 480,5 & 800 & 700 & 83274,87 & 584,5 & 2793,6 \\
\hline 2013 & 800 & 728 & 900 & 710 & 95766,11 & 701,4 & 2978,3 \\
\hline 2014 & 991,75 & 899,02 & 980 & 728 & 143649,165 & 1052,1 & 3374 \\
\hline 2015 & 6938 & 938,86 & 147 & 888,7808 & 139976,3 & 816,93 & 3746 \\
\hline 2016 & 1033,25 & 978,7 & 143,58 & 897,6409 & 158468,5 & 849,86 & -212682 \\
\hline 2017 & & 391,5 & 140,63 & 906,501 & 176960,7 & 882,79 & -210041 \\
\hline
\end{tabular}

Проведений кореляційно-регресійний аналіз структури ціни та розрахунок прогнозних значень ціни на продукцію підприємств машинобудування був здійснений на основі фінансової звітності підприємств. В основі використаної інформаційної бази для розрахунків ціни виступили тільки дані про витрати та собівартість продукції підприємств машинобудування. Проте, запропонований метод ціноутворення є можливим для використання при розрахунках ціни на основі даних про обсяги попиту та ціни конкурентів. Апробація результатів розрахунку ціни на основі інформації 
про попит та ціни конкурентів буде представлений в подальших дослідженнях.

Висновки. Проведений вище аналіз дозволив зробити висновок, що підприємства машинобудування при встановленні ціни використовують витраті методи ціноутворення. В процесі проведення кореляційнорегресійного аналізу були виявлені 3 основних витратних фактора, які мають найбільший вплив в структурі ціни на продукцію машинобудування. Основним завданням дослідження було вдосконалення методів ціноутворення 3 використанням розрахунку найбільш питомих факторів в структурі ціни. Метод розрахунку питомої ціни повинен базуватися на питомій вазі кожного фактору в структурі ціни. Цей підхід дозволить враховувати низьку факторів ціноутворення, які притаманні галузі машинобудування. Крім того, цей підхід до ціноутворення дозволяє об`єктивно відокремлювати специфічні фактори, які мають місце в різних підгалузях машинобудування та враховувати їх при формуванні ціни на свою продукцію.

\section{Література:}

1. Балабанова Л.В.Цінова політика торговельного підприємства в умовах маркетингової орієнтації: [Монографія] / Л.В. Балабанова, О.В. Сардак - Донецьк: ДонДУЕТ ім. М. Туган-Барановського, 2003. - 149c.

2. Друкер П. Энциклопедия менеджмента: 10-е изд. / Друкер П.; [пер. с англ.]. - М.: Издательский дом «Вильямс», 2004. - 432 с.:іл.

3. Котлер Ф. 300 ключевых вопросов маркетинга: отвечает Ф. Котлер/ Котлер Ф.; [Пер. с анг]. - М.: ЗАО «Олимп-бизнес», 2006. - 224с.

4. Котлер Ф. Маркетинг менеджмент/ Котлер Ф.; [пер. 3 англ.] - СПб. : Питер Ком, 1999. $896 \mathrm{c.}$

5. Окландер М.А. Маркетингова цінова політика: Навчальний посібник. [для студ. вищ. навч. закл.] / Окландер М.А.,Чукурна Е.П. - Київ: ЦУЛ, 2012- 222 с.

6. Портер М. Конкуренция / Портер М. [пер. с англ.]. - М. : Издательский дом «Вильямс», 2005.- 608c.

7. Ревуцька Н.В. Формування споживчої цінності продукції як основа конкурентоспроможності підприємства / Ревуцька Н.В. // Теоретичні та прикладні питання економіки. -2013. Випуск 28,T.1. -с. 239-246

8. Шульгіна Л.М. Еволюція наукових поглядів щодо поняття «споживча цінність товару» / Шульгіна Л.М., Мельничук В.М. // Маркетинг і менеджмент інновацій. - №2, 2001. - с. 74-80 